\section{Nitrogen Nutrition of Spathiphyllum 'Sensation' Grown in Sphagnum Peat- and Coir-based Media with Two Irrigation Methods}

\author{
Albert T.Y. Mak ${ }^{1}$ and D.M. Yeh ${ }^{2}$ \\ Department of Horticulture, National Taiwan University, Taipei, Taiwan, \\ Republic of China \\ Additional index words. ebb-and-flow irrigation, peace lily, tissue analysis, stomatal \\ conductance, transpiration, chlorophyll content
}

\begin{abstract}
Effects of nitrogen application on growth, stomatal conductance, transpiration, and chlorophyll content were studied in Spathiphyllum Schott 'Sensation' grown in sphagnum peat $(\mathrm{SP})$ - and coir dust $(\mathrm{CD})$-based media with top-irrigation or subirrigation. Maximum shoot dry weight occurred at $8 \mathrm{mM}$ N in plants grown in SP-based medium under top-irrigation and subirrigation, and in CD-based medium under subirrigation. For plants in CD-based medium under top-irrigation, maximum shoot dry weight was obtained at $16 \mathrm{~mm}$ N. In SP- or CD-based medium, shoot dry weight was greater at 4 and $8 \mathrm{~mm} \mathrm{~N}$ under subirrigation than under top-irrigation. Stomatal conductance and transpiration were reduced by nitrogen deficiency $(0 \mathrm{~N})$, greatly enhanced by $4 \mathrm{~mm} \mathrm{~N}$, and decreased gradually at higher $\mathbf{N}$ levels. Chlorophyll content increased with increasing $\mathbf{N}$ concentration up to $8 \mathrm{~mm}$. The percentage of maximum total dry weight increased quadratically as leaf $\mathrm{N}$ content increased from $1.5 \%$ to $3.5 \%$. Nitrogen at 16 and $32 \mathrm{~mm}$ increased the number of leaves with marginal necrosis. Reduced growth and more leaves with marginal necrosis occurred in SP- or CD-based media with EC $>1.25 \mathrm{dS} \cdot \mathrm{m}^{-1}$ in the middle and bottom layers.
\end{abstract}

Most foliage plants are grown in sphagnum peat (SP)-based soilless growing media with constant liquid fertilization rates (Poole et al., 1981). Leaching is commonly required to prevent soluble salts from accumulating in SP-based media, while excess nutrients in the leachate result in contaminated runoff that enters the ground and surface waters (Dole et al., 1994; Yelanich and Biernbaum, 1993). Recirculatory irrigation systems, such as ebband-flow (EF), have been highly publicized as one way to reduce water use and runoff, and EF subirrigation is already an accepted technique in European greenhouse production (Molitor, 1990). Reduced optimum fertilizer application rates under subirrigation in SPbased media have been reported for several foliage plants, including Hedera helix L. (Holcomb et al., 1992) and Spathiphyllum Schott 'Petite' (Kent and Reed, 1996). How-

Received for publication 18 Apr. 2000. Accepted for publication $29 \mathrm{Aug}$. 2000. This paper is a portion of a thesis submitted by Albert T.Y. Mak. We gratefully acknowledge financial support from the National Science Council of the Republic of China. Use of trade names does not imply endorsement of products named or criticism of similar products not mentioned. The cost of publishing this paper was defrayed in part by the payment of page charges. Under postal regulations, this paper therefore must be hereby marked advertisement solely to indicate this fact.

${ }^{1}$ Graduate Student.

${ }^{2}$ Associate Professor; to whom reprint request should be addressed. E-mail address: dmyeh@ ms.cc.ntu.edu.tw ever, information on foliage plants grown in coir dust (CD)-based media under subirrigation is presently limited. Before the inherent benefits of EF subirrigation can be exploited, the fertilization levels must be determined, particularly of $\mathrm{N}$, that result in optimum plant nutrition in growing media containing $\mathrm{CD}$, which has a lower $\mathrm{C}: \mathrm{N}$ ratio than $\mathrm{SP}$ and from which $\mathrm{N}$ is removed more rapidly (Handreck, 1993a; Merrow, 1994).

Sphagnum peat has desirable properties, such as high water-holding capacity and cation exchange capacity (CEC) (Biernbaum, 1992). Environmental and economical concerns have generated interest in seeking alternatives for SP because of the detrimental effects of peat harvesting on wetland ecosystems (Evans et al., 1996; Handreck, 1993b). Coir dust is reported to have many physical characteristics that make it equal or superior to SP as a component in growing media (Prasad, 1997), including a lower CEC (Evans et al., 1996; Prasad, 1997). Coir dust has been used successfully in the production of tropical foliage plants, including Dieffenbachia maculata [(Lodd.) G. Don] 'Camille' (Stamps andEvans, 1997), Ravenea rivularis Jumelle and Perrier, and Anthurium Schott 'Lady Jane' (Merrow, 1995), Dracaena marginata Bak., and Spathiphyllum Schott 'Petite' (Stamps and Evans, 1999).

Spathiphyllum is one of the most popular tropical foliage plants grown commercially (Stamps and Evans, 1999). Optimal N fertilization levels for Spathiphyllum in SP-based media have been reported for constant liquid fertilizer (Campos and Reed, 1993) and for a subirrigation system (Kent and Reed, 1996), but leaf mineral contents were not measured in these studies. No published reports have been found on the optimal $\mathrm{N}$ fertilization levels for Spathiphyllum grown in CD-based media under top-irrigation or subirrigation. The aim of the present work was to determine the effects of $\mathrm{N}$ level on growth and quality of Spathiphyllum Schott 'Sensation'TM (Pat \#6964) grown in SP- and CD- based media under top-irrigation and subirrigation.

\section{Materials and Methods}

The experiment was arranged in a splitplot factorial design, with $\mathrm{N}$ level and irrigation method as the two main plots and growing medium as the subplot. There were six plants in each treatment. On 20 Apr. 1998, tissuecultured plants of Spathiphyllum Schott 'Sensation' at the six macroscopic leaf stage were planted in growing medium in 11-cm-diameter $\times 9-\mathrm{cm}$-tall $(615-\mathrm{mL})$ pots. Two growing media used commercially in containerized foliage plant production were prepared, with a SP-based mix of 1 sphagnum peat (Fafard No. 1; Conrad Fafard Inc., Agawam, Mass.) : 1 perlite : 1 treefern (by volume), and a CDbased mix of 1 coir dust (Coco peat; Uniceyl Co., Colombo, Sri Lanka): 1 perlite : 1 treefern (by volume). Plants in each plot were irrigated independently when the surface of the growing medium began to dry. For the top-irrigation treatments, the amount of irrigation solution applied yielded a 0.33 leaching fraction. For the subirrigation treatments, ten $70-\mathrm{cm} \times$ $40-\mathrm{cm}$ subirrigation trays were manually flooded with irrigation solution to a depth of 3 $\mathrm{cm}$. Trays required 5 to $6 \mathrm{~min}$ to fill and 4 to 6 min to drain and were held flooded for a maximum of $25 \mathrm{~min}$ at each irrigation, and then irrigation solutions were recycled to the reservoirs. Irrigation solutions were refilled when the level of reservoirs decreased by half.

Irrigation solutions contained (mM): $1.0 \mathrm{P}$, $3.0 \mathrm{~K}, 2.0 \mathrm{Ca}$, and $0.5 \mathrm{Mg}$, with $0,4,8,16$, or $32 \mathrm{~N}$ obtained from $0.5 \mathrm{MgSO}_{4}, 1.0 \mathrm{CaCl}_{2}, 1.5$ $\mathrm{K}_{2} \mathrm{SO}_{4}, 0.5 \mathrm{Ca}\left(\mathrm{H}_{2} \mathrm{PO}_{4}\right)_{2}, 0.5 \mathrm{CaSO}_{4}$, and 0,2 , 4,8 , or $16 \mathrm{NH}_{4} \mathrm{NO}_{3}$ in tap water. Solution $\mathrm{pH}$ was adjusted to 6.0. Samples of individual subirrigation solutions were taken at each irrigation for analysis of electrical conductivity (EC) and $\mathrm{pH}$. The EC was measured with a model 44600 conductivity/TDS meter (Hach Co., Loveland, Colo.), and $\mathrm{pH}$ was measured using a Hach EC10 pH meter, with a model 50200 electrode. Plants were grown in a 54\% shaded greenhouse, with an average noontime light intensity of $600 \mu \mathrm{mol} \cdot \mathrm{m}^{-2} \cdot \mathrm{s}^{-1}$ and mean daily temperature of $29^{\circ} \mathrm{C}$.

Physical properties of preplant growing media were measured following the methods described by Bragg and Chambers (1988). The EC and $\mathrm{pH}$ were determined using 1 root medium : 2 water (by volume) extracts. Mineral contents in the growing media were determined on saturated media extracts (Warncke and Krauskopf, 1983). Phosphorus, K, Ca, $\mathrm{Mg}$, and $\mathrm{Na}$ were determined with an inductively coupled argon plasma (ICP) emission 
spectrometer (Thermo Jarrell Ash Co., Boston). There were four replications for these preplant measurements.

On 11 Oct. 1998, the growing medium and roots of each plant were divided into top, middle, and bottom zones, each $\approx 2 \mathrm{~cm}$ thick, with a sharp knife. Discs were pulverized and samples from each zone were collected for $1: 2$ extracts, then $\mathrm{pH}$ and $\mathrm{EC}$ measurement. Shoot and root dry weight, number of leaves with marginal necrosis, and chlorophyll contents were recorded. Two $0.65-\mathrm{cm}$ discs from each of the two youngest fully expanded leaves of six plants were used for $N, N$-dimethylformamide (DMF) extraction of chlorophyll (Moran, 1982). Chlorophyll contents were measured using a spectrophotometer (U-2001, Hitachi, Tokyo) and calculations according to Inskeep and Bloom (1985). Relative chlorophyll content of the youngest fully expanded leaves was also measured in situ on 11 Oct. 1998 with a chlorophyll meter (SPAD-502, Minolta Camera Co., Tokyo). Stomatal conductance and transpiration were measured on similar leaves with a steady-state porometer (LI-1600, LICOR, Lincoln, Nebr.). Total N concentration of the youngest fully expanded leaves was determined with the Kjeldahl procedure and $\mathrm{P}$, $\mathrm{K}, \mathrm{Ca}, \mathrm{Mg}$ and $\mathrm{Na}$ were measured with an ICP spectrometer. Data were tested using the analysis of variance procedures of SAS (SAS Institute, Cary, N.C.). Regression analysis was used to describe the relationships between leaf $\mathrm{N}$ content and maximum total dry weight, chlorophyll content and chlorophyll meter readings (SPAD-502 values).

\section{Results and Discussion}

Properties of preplant growing medium. SP- and CD-based media did not differ in air filled porosity ( $33.6 \%$ to $38.9 \%$ by volume), water-holding capacity $(51.4 \%$ to $53.7 \%$ by volume), total porosity ( $87.3 \%$ to $90.3 \%$, by volume), or bulk density ( 0.13 to $\left.0.15 \mathrm{~g} \cdot \mathrm{cm}^{-3}\right)$. Physical properties of the media were within the recommended ranges for growing foliage plants (Poole et al., 1981).

The CD-based medium had higher $\mathrm{K}$ and $\mathrm{Na}$ contents and EC but had lower $\mathrm{P}, \mathrm{Ca}$ and $\mathrm{Mg}$ contents than did the SP-based medium (Table 1). High EC values in some sources of $\mathrm{CD}$ are caused by high $\mathrm{Na}, \mathrm{K}$, and $\mathrm{Cl}$ contents, because coconut plants are fertilized with $\mathrm{KCl}$ and raw coconut husks are soaked in saline water during processing (Evans et al., 1996; Handreck, 1993b). The SP- and CD-based media did not differ in $\mathrm{pH}$ (5.8 to 5.9), and values were within the optimum range from 5.5 to 6.5 , as recommended for most greenhouse crops (Poole et al., 1981; Warncke and Krauskopf, 1983).

Shoot dry weight. For plants grown in both $\mathrm{SP}$ - and CD-based media with subirrigation or top-irrigation, the $0-\mathrm{N}$ treatments significantly reduced shoot dry weight, whereas a small increase in $\mathrm{N}$ level to $4 \mathrm{~mm}$ sharply enhanced it (Fig. $1 \mathrm{~A}$ and B, Table 2). For plants grown in SP-based medium, shoot dry weight increased up to $8 \mathrm{~mm} \mathrm{~N}$, then declined gradually (Fig. 1A, Table 2). Leaf number and leaf area
Table 1. Preplant mineral nutrient content, electrical conductivity (EC), and $\mathrm{pH}$ in extracts of sphagnum peat (SP)- or coir dust (CD)-based growing media.

\begin{tabular}{|c|c|c|c|c|c|c|}
\hline \multirow[b]{2}{*}{ Growing medium } & $\mathrm{P}$ & $\mathrm{K}$ & $\mathrm{Ca}$ & $\mathrm{Mg}$ & $\mathrm{Na}$ & \multirow{2}{*}{$\begin{array}{c}\mathrm{EC} \\
\left(\mathrm{dS} \cdot \mathrm{m}^{-1}\right)\end{array}$} \\
\hline & \multicolumn{5}{|c|}{$\left(\mathrm{mg} \cdot \mathrm{L}^{-1}\right)$} & \\
\hline SP-based & 12.6 & 93.4 & 67.9 & 61.1 & 26.4 & 1.25 \\
\hline CD-based & 4.2 & 282.6 & 3.4 & 1.7 & 144.7 & 2.16 \\
\hline Significance & $* * *$ & $* * *$ & $* * *$ & $* * *$ & $* * *$ & $* * *$ \\
\hline
\end{tabular}

${ }^{* * *}$ Significant at $P \leq 0.001$.

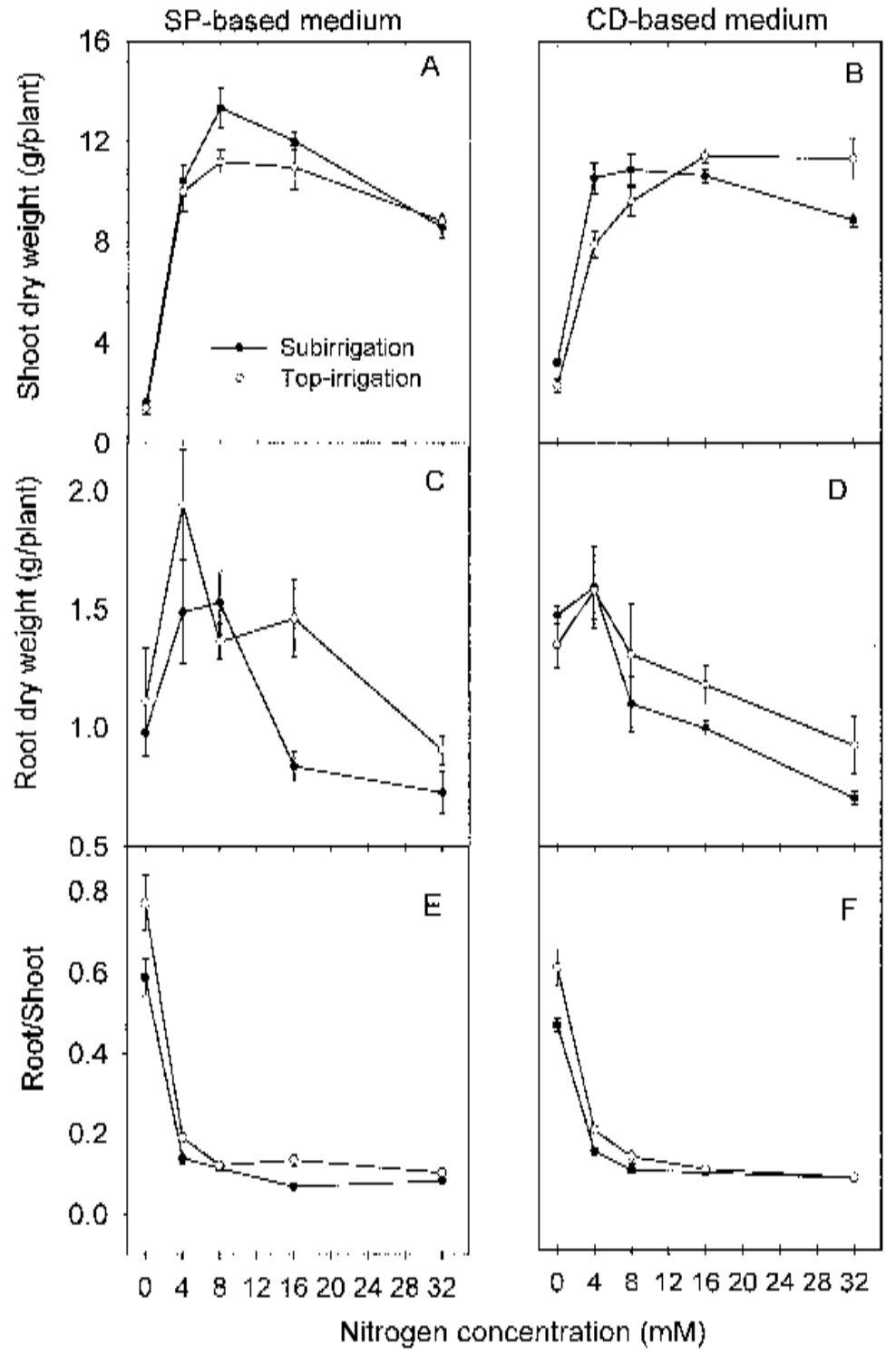

Fig. 1. Effects of nitrogen concentration on growth of Spathiphyllum 'Sensation' grown in SP-and CD-based media under top-irrigation and subirrigation. Bars represent standard error of the mean.

Table 2. Analysis of variance for the effects of five nitrogen levels, two irrigation methods, and two growing media on growth, stomatal conductance (Cond.), transpiration (Trans.), chlorophyll content, and number of necrotic leaves in Spathiphyllum 'Sensation'.

\begin{tabular}{|c|c|c|c|c|c|c|c|}
\hline \multirow[b]{2}{*}{ Source } & \multicolumn{2}{|c|}{ Dry weight } & \multirow{2}{*}{$\begin{array}{c}\text { Root : shoot } \\
\text { ratio }\end{array}$} & \multirow[b]{2}{*}{ Cond. } & \multirow[b]{2}{*}{ Trans. } & \multirow{2}{*}{$\begin{array}{c}\text { Chlorophyll } \\
\text { content }\end{array}$} & \multirow{2}{*}{$\begin{array}{c}\text { No. of } \\
\text { necrotic leaves }\end{array}$} \\
\hline & Shoot & $\overline{\text { Root }}$ & & & & & \\
\hline$\overline{\text { Nitrogen }(\mathrm{N})}$ & $* * *$ & $* * *$ & **** & $* * *$ & $* * *$ & $* * *$ & **** \\
\hline Irrigation (I) & NS & $* *$ & $* *$ & NS & $*$ & $* * *$ & NS \\
\hline$(\mathrm{I}) \times(\mathrm{N})$ & $* *$ & NS & $* * *$ & $*$ & NS & NS & NS \\
\hline Medium (M) & NS & NS & $* *$ & NS & NS & $*$ & NS \\
\hline (I) $\times(\mathrm{M})$ & NS & NS & NS & NS & NS & NS & NS \\
\hline$(\mathrm{N}) \times(\mathrm{M})$ & $* * *$ & $* *$ & $* * *$ & NS & NS & NS & NS \\
\hline (I) $\times(\mathrm{N}) \times(\mathrm{M})$ & $* *$ & NS & NS & NS & NS & NS & NS \\
\hline
\end{tabular}

Ns, $, * *, * * *$ Nonsignificant or significant at $P \leq 0.05,0.01$, or 0.001 , respectively. 
exhibited identical responses (data not shown). This was consistent with the optimum N levels at 8 to $10 \mathrm{~mm}$ for Spathiphyllum 'Petite' in SPbased medium under subirrigation (Kent and Reed, 1996), and represented the lower end of the optimum $\mathrm{N}$ level ranges from 7.5 to $30 \mathrm{~mm}$ determined for fertigation in top irrigation (Campos and Reed, 1993).

For plants grown in CD-based medium, maximum shoot dry weight also occurred at 8 $\mathrm{mM} N$ under subirrigation, above which it decreased. In contrast, the maximum growth was recorded at 16 and $32 \mathrm{~mm} \mathrm{~N}$ in plants under top-irrigation (Fig. 1B, Table 2). Leaf number and leaf area behaved similarly (data not shown). Therefore, subirrigation could sustain adequate Spathiphyllum growth at lower $\mathrm{N}$ levels, possibly by reducing leaching, and thus could save $\mathrm{N}$ fertilizer. For plants with top-irrigation, both the $8 \mathrm{~mm} \mathrm{~N}$ in SP-based medium and $16 \mathrm{~mm} \mathrm{~N}$ in CD-based medium treatments produced similar shoot dry weights (Fig. $1 \mathrm{~A}$ and $\mathrm{B}$, Table 2). The higher $\mathrm{N}$ concentration required for maximum growth in CD-based medium with top-irrigation could be explained in two ways. First, $\mathrm{CD}$ has a lower CEC than does SP and thus nutrients are more easily leached (Evans et al., 1996; Prasad, 1997). Second, CD has both a lower $\mathrm{C} / \mathrm{N}$ ratio and a faster $\mathrm{N}$ drawdown index than does SP (Handreck, 1993a; Merrow, 1994). Plants nearly as large as those in SP could be produced in $\mathrm{CD}$, indicating that $\mathrm{CD}$ could be used as an acceptable substitute for SP for Spathiphyllum production.

Root dry weight and root: shoot ratio. For plants grown by both irrigation methods in SPor CD-based media, maximum root dry weight was obtained at about $4 \mathrm{~mm} \mathrm{~N}$ (Fig. $1 \mathrm{C}$ and D, Table 2). The decreased root and/or shoot growth at higher $\mathrm{N}$ levels may indicate the salinity tolerance limits of Spathiphyllum.

The $0 \mathrm{~N}$ treatment produced the highest root/shoot ratio, but increasing $\mathrm{N}$ from 8 to 32 $\mathrm{mM}$ did not affect the ratio (Fig. $1 \mathrm{E}$ and $\mathrm{F}$, Table 2). Nitrogen deficiency may have reduced the supply of photosynthates by decreasing leaf number and area, but increasing root-shoot partitioning of photoassimilates. Similar examples of $\mathrm{N}$ deficiency increasing root : shoot ratio are well-documented, and this preferential partitioning is dependent on phloem mobility and hence on $\mathrm{N}$ cycling from shoot to root (Marschner et al., 1996).

Top-irrigation generally increased root dry weight more than did subirrigation and produced small but significant increases in rootshoot ratio (Fig. 1C-F, Table 2). In a previous report on poinsettias (Euphorbia pulcherrima Willd. Ex. Klotzsch), subirrigated plants had lower root : shoot ratios than did top-irrigated plants, particularly at high nutrient levels (Argo and Biernbaum, 1995).

Stomatal conductance and transpiration. Regardless of medium, stomatal conductance and transpiration paralleled root growth patterns in response to $\mathrm{N}$ levels (Fig. 2, Table 2). Stomatal conductance and transpiration were minimal at $0 \mathrm{~N}$, greatly enhanced by only a small increase in $\mathrm{N}$ concentration to $4 \mathrm{~mm}$, and decreased gradually with increasing $\mathrm{N}$ above 4

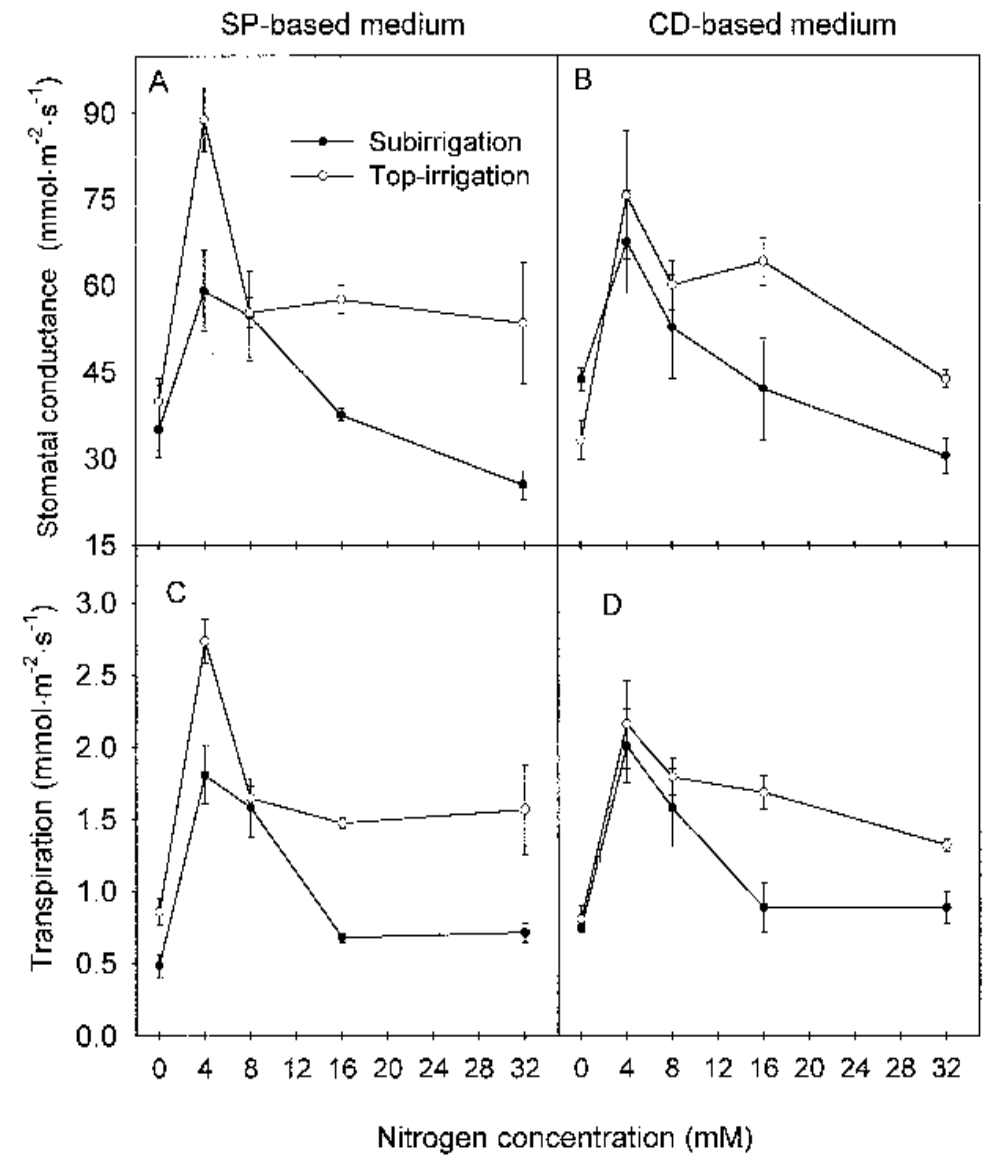

Fig. 2. Stomatal conductance and transpiration of Spathiphyllum 'Sensation' grown in SP-and CD-based media at five $\mathrm{N}$ concentrations under top-irrigation and subirrigation. Bars represent standard error of the mean.

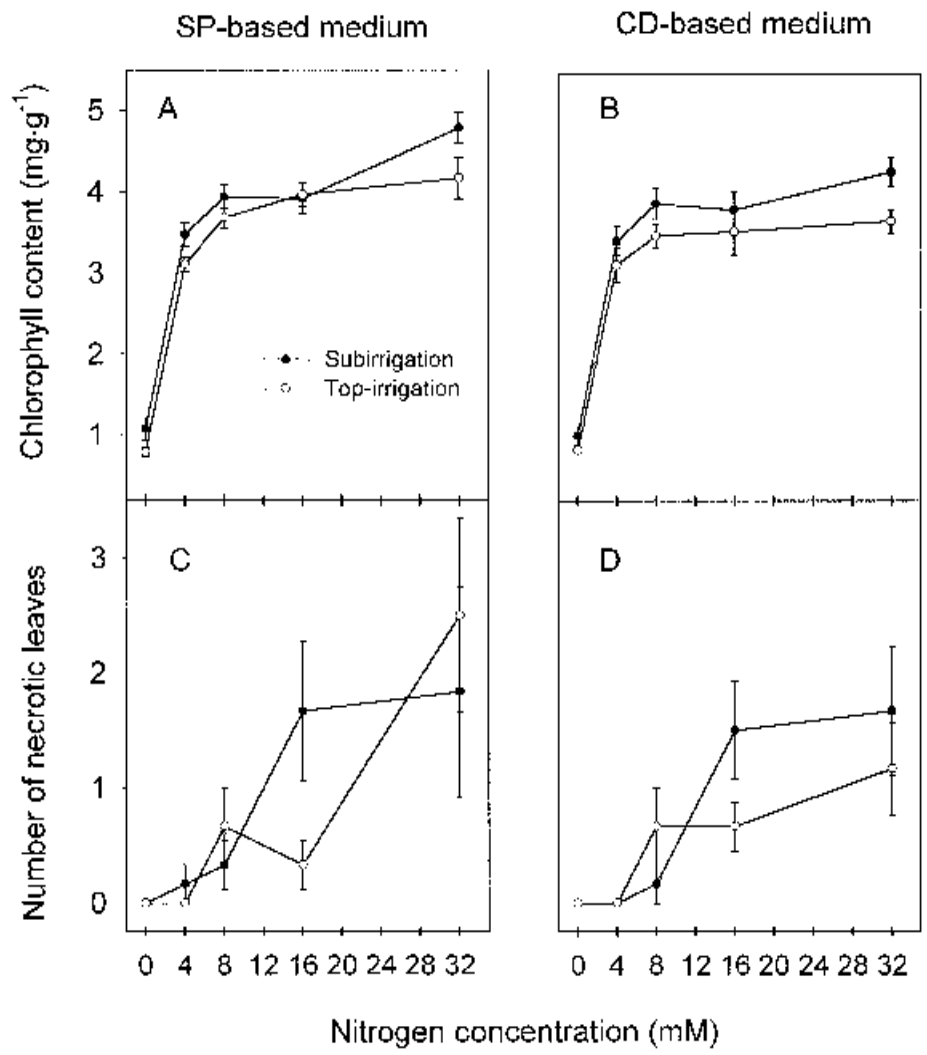

Fig. 3. Effects of nitrogen concentration on chlorophyll content and number of necrotic leaves in Spathiphyllum 'Sensation' grown in SP- and CD-based media under top-irrigation and subirrigation. Bars represent standard error of the mean. 


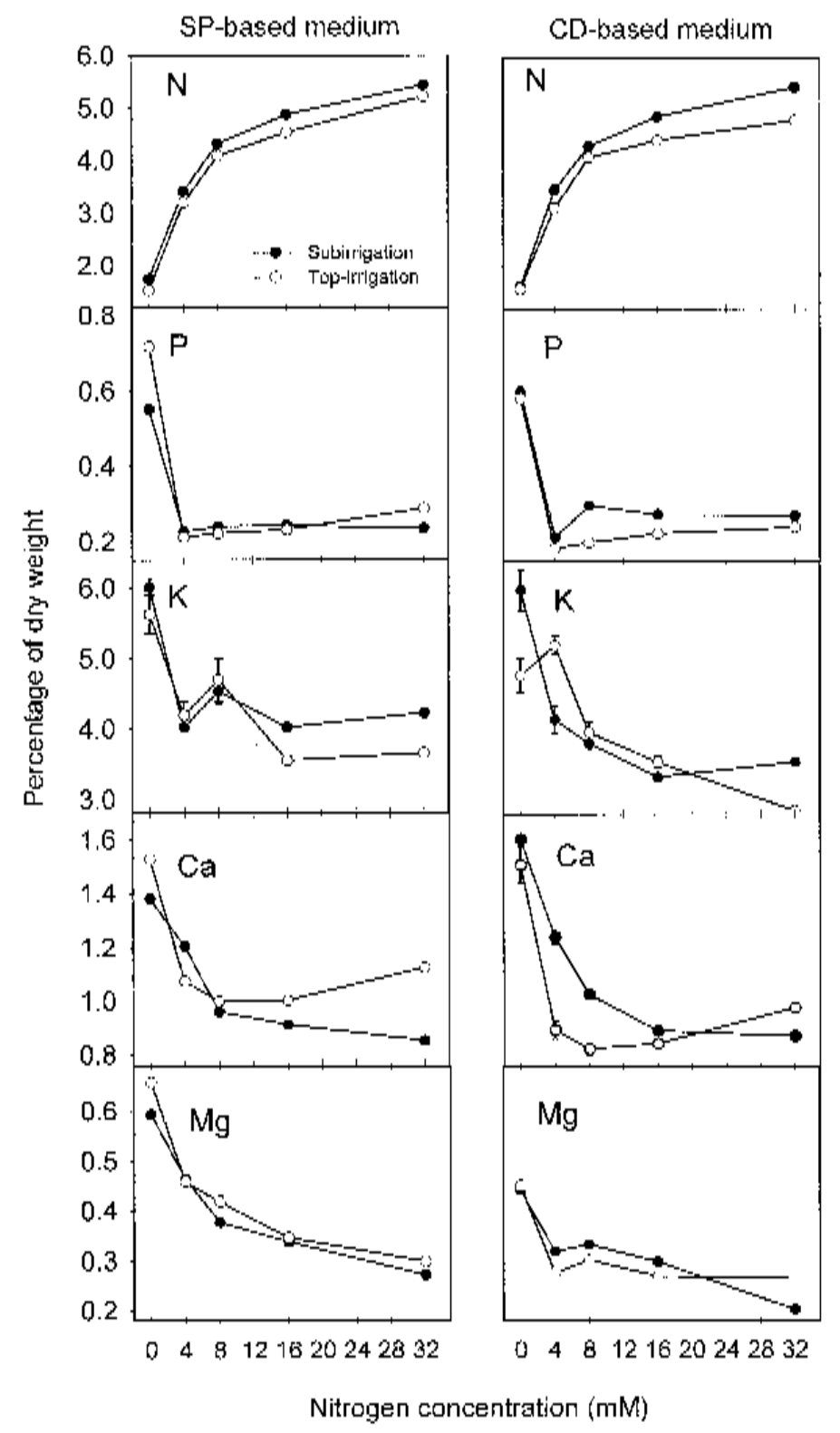

Fig. 4. Leaf macroelement contents of Spathiphyllum 'Sensation' grown in SP- and CDbased media at five $\mathrm{N}$ concentrations under top-irrigation and subirrigation. Bars represent standard error of the mean.

mM. Plants grown with subirrigation had lower stomatal conductance and transpiration than did those grown with top-irrigation, particularly at 8 and $16 \mathrm{~mm}$ N. Radin and Boyer (1982) also noted that $\mathrm{N}$ level can affect stomatal closure and transpiration, which relate well with plant water status.

Chlorophyll content and number of leaves with marginal necrosis. Well-developed, dark green leaves of Spathiphyllum are considered to be a measure of good plant quality. Chlorophyll content increased with increasing $\mathrm{N}$ concentration up to $8 \mathrm{~mm}$, then remained almost constant. Plants grown with subirrigation generally had slightly, but significantly higher, chlorophyll content than did plants grown with top-irrigation (Fig. $3 \mathrm{~A}$ and B, Table 2).

The number of leaves with marginal necrosis increased with increasing $\mathrm{N}$ level from 0 to $32 \mathrm{~mm}$ (Fig. $3 \mathrm{C}$ and D, Table 2). High fertilizer levels have been reported to increase numbers of necrotic leaves in Spathiphyllum (Chase, 1997).

Leaf mineral content. Leaf $\mathrm{N}$ content increased dramatically with increasing $\mathrm{N}$ level from 0 to $8 \mathrm{~mm}$, then increased more slowly (Fig. 4). Plants supplied with 8 and $16 \mathrm{~mm} \mathrm{~N}$ had leaf $\mathrm{N}$ contents ranging from $3.3 \%$ to $5 \%$, as recommended for healthy Spathiphyllum (Mills and Jones, 1991), but those grown with $32 \mathrm{~mm} \mathrm{~N}$ had a leaf $\mathrm{N}$ content higher than the recommended upper limit.

Leaf $\mathrm{P}, \mathrm{K}, \mathrm{Ca}$ and $\mathrm{Mg}$ contents decreased sharply with increasing $\mathrm{N}$ level from 0 to 4 $\mathrm{mM}$, decreased gradually from 4 to $8 \mathrm{mM}$, and changed little thereafter (Fig. 4). Leaf P, K, Ca and $\mathrm{Mg}$ contents in all treatments were within the optimum ranges, i.e., $\mathrm{P}(0.2 \%$ to $1.0 \%), \mathrm{K}$ (2.3\% to $6.0 \%), \mathrm{Ca}(0.8 \%$ to $2.0 \%)$, and $\mathrm{Mg}$ ( $0.2 \%$ to $1.0 \%)$, as recommended by Mills and Jones (1991). Tissue analysis revealed no difference in leaf $\mathrm{Na}$ content among treatments (data not shown). Number of leaves with marginal necrosis was little affected by the higher $\mathrm{Na}$ content in the preplant CD-based medium used in the present study.

Relationships between leaf $N$ content, chlorophyll content and growth. The percentages of maximum total dry weight for all treatments were calculated and plotted against leaf $\mathrm{N}$ contents (Fig. 5A). Growth increased quadratically as leaf $\mathrm{N}$ content increased from $1.5 \%$ to $3.5 \%$, and plateaued between $3.5 \%$ and $4.5 \%$. Growth decreased above $4.5 \% \mathrm{~N}$, which is close to the upper limit of $5 \% \mathrm{~N}$ as recommended for Spathiphyllum (Mills and Jones, 1991). Regressions of chlorophyll content, as measured by extraction of leaf disks or with a SPAD chlorophyll meter, on leaf $\mathrm{N}$ content showed highly significant curvilinear relationships (Fig. $5 \mathrm{~B}$ and $\mathrm{C}$ ). The SPAD measurements showed a trend similar to the percentage of maximum growth with respect to leaf $\mathrm{N}$ content. This nondestructive, in situ, chlorophyll meter could aid in monitoring leaf $\mathrm{N}$ status of Spathiphyllum.

Growing medium EC. The EC in the growing media increased with increasing $\mathrm{N}$ level, and EC was higher in the top layer than in the middle and bottom layers (Fig. 6). A similar trend in salt stratification was reported for 


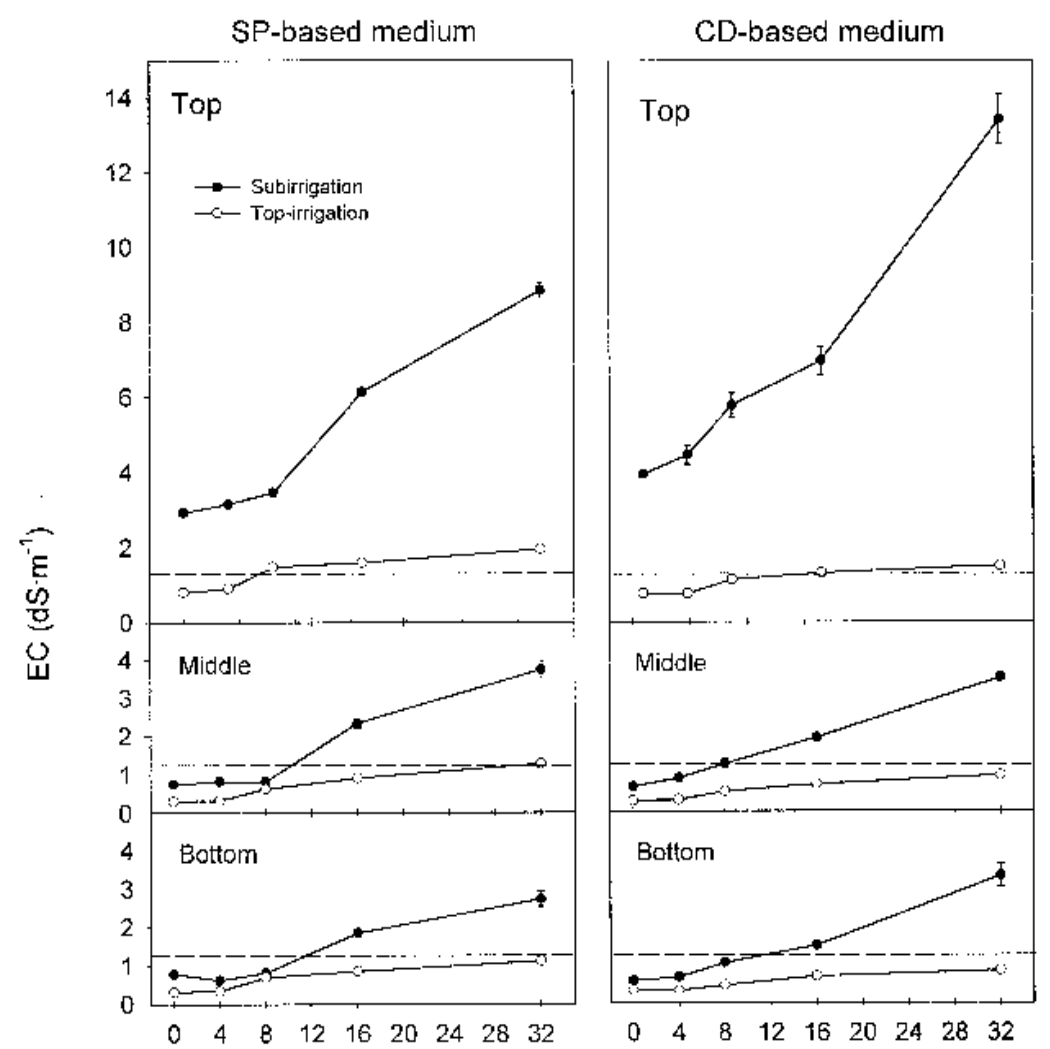

Nitrogen concentration ( $\mathrm{mm}$ )

Fig. 6. Electrical conductivity (EC) of extracts from SP- and CD-based media from the top, middle, and bottom zones of the container. Dashed line at $1.25 \mathrm{dS} \cdot \mathrm{m}^{-1}$ represents the upper limit of $\mathrm{EC}$ recommended by Warncke and Krauskopf (1983). Bars represent standard error of the mean.

plants grown with subirrigation (Kent and Reed, 1996). Salt accumulation in the top layer is due primarily to surface evaporation from the medium (Argo and Biernbaum, 1995). For top-irrigation treatment, all EC values in the middle and bottom layers were below 1.25 $\mathrm{dS} \cdot \mathrm{m}^{-1}$, while those in the top layers exceeded $1.25 \mathrm{dS} \cdot \mathrm{m}^{-1}$ at 16 and $32 \mathrm{~mm} \mathrm{~N}$. For the subirrigation treatment, EC in the top layers ranged from 3 to $14 \mathrm{dS} \cdot \mathrm{m}^{-1}$, while that in the middle and lower layers exceeded $1.25 \mathrm{dS} \cdot \mathrm{m}^{-1}$ only at 16 and $32 \mathrm{~mm} \mathrm{~N}$. Salt accumulation in the top layer is considered to be safe for growing plants under subirrigation, as root systems are concentrated in the middle and bottom layers (Kent and Reed, 1996). Plants grown in $\mathrm{SP}$ - or CD-based media with EC $>1.25 \mathrm{dS} \cdot \mathrm{m}^{-1}$ in the middle and bottom layers grew less and had more necrotic leaves (Figs. 1, 3, and 6), indicating that $1.25 \mathrm{dS} \cdot \mathrm{m}^{-1}$ is the upper limit for the optimum growth of Spathiphyllum. Similar EC values in the middle and bottom layers were measured in both SP- and CDbased medium under subirrigation (Fig. 6).

\section{Conclusions}

The growing medium containing $\mathrm{CD}$, as an alternative to SP, was conducive for Spathiphyllum production with maximum shoot dry weights at $8 \mathrm{~mm} \mathrm{~N}$ under subirriga- tion and $16 \mathrm{~mm} \mathrm{~N}$ under top-irrigation. High $\mathrm{N}$ at 16 or $32 \mathrm{~mm}$ with subirrigation increased $\mathrm{EC}$, particularly in the top layer of CD-based medium, which increased the number of leaves with marginal necrosis and reduced root dry weight, stomatal conductance, and transpiration (Figs. 1-3, 6). The higher EC of the CDbased medium in subirrigation imparted a salinity stress, a part of which may have been manifested as a water stress at the higher $\mathrm{N}$ concentrations. That stomatal closure is the main cause for reduced transpiration as water stress develops is well documented (Hsiao, 1973).

\section{Literature Cited}

Argo, W.R. and J.A. Biernbaum. 1995. The effect of irrigation method, water-soluble fertilization, preplant nutrient change, and evaporation on early vegetative and root growth of poinsettia. $\mathrm{J}$. Amer. Soc. Hort. Sci. 120:163-169.

Biernbaum, J.A. 1992. Root-zone management of greenhouse container-crops to control water and fertilizer use. HortTechnology 2:127-132.

Bragg, N.C. and B.J. Chambers. 1988. Interpretation and advisory applications of compost airfilled porosity (AFP) measurements. Acta Hort. 221:35-44.

Campos, R. and D.W. Reed. 1993. Determination of constant-feed liquid fertilization levels for Spathiphyllum 'Petite' and Dieffenbachia 'Camille'. J. Environ. Hort. 11:22-24.
Chase, A.R. 1997. Foliage plant diseases. APS Press, St. Paul, Minn.

Dole, J.M., J.C. Cole, and S.L. von Broembsen. 1994. Growth of poinsettias, nutrient leaching, and water-use efficiency respond to irrigation methods. HortScience 29:858-864.

Evans, M.R., S. Konduru, and R.H. Stamps. 1996. Source variation in physical and chemical properties of coconut coir dust. HortScience 31:965967.

Handreck, K.A. 1993a. Immobilisation of nitrogen in potting media. Acta Hort. 342:121-126.

Handreck, K.A. 1993b. Properties of coir dust, and its use in the formulation of soilless potting media. Commun. Soil Sci. Plant Anal. 24:349363.

Holocomb, E.J., S. Gamez, D. Beattie, and G.C. Elliott. 1992. Efficiency of fertigation programs for baltic ivy and asiatic lily. HortTechnology 2:43-46.

Hsiao, T.C. 1973. Plant responses to water stress. Annu. Rev. Plant Physiol. 24:519-570.

Inskeep, W.P. and P.R. Bloom. 1985. Extinction coefficients of chlorophyll a and b in $N, N$ dimethylformamide and $80 \%$ acetone. Plant Physiol. 77:483-485.

Kent, M.W. and D.W. Reed. 1996. Nitrogen nutrition of New Guinea impatiens 'Barbados' and Spathiphyllum 'Petite' in a subirrigation system. J. Amer. Soc. Hort. Sci. 121:816-819.

Marschner, H., E.A. Kirkby, and I. Cakmak. 1996. Effect of mineral nutritional status on shoot-root partitioning of photoassimilates and cycling of mineral nutrients. J. Expt. Bot. 47:1255-1263.

Merrow, A.W. 1994. Growth of two subtropical ornamentals using coir (coconut mesocarp pith) as a peat substitute. HortScience 29:1484-1486.

Merrow, A.W. 1995. Growth of two tropical foliage plants using coir dust as a container medium amendment. HortTechnology 5:237-239.

Mills, H. A. and J. B. Jones, Jr. 1991. Plant analysis handbook. MicroMacro, Athens, Ga.

Molitor, H. D. 1990. The European perspective with emphasis on subirrigation and recirculation of water and nutrients. Acta Hort. 272:165-173.

Moran, R. 1982. Formulae for determination of chlorophyllous pigments extracted with $\mathrm{N}, \mathrm{N}$ dimethylformamide. Plant Physiol. 65:478-479.

Poole, R.T., C.A. Conover, and J.N. Joiner. 1981. Soils and potting mixes. p. 179-202. In: J.N. Joiner (ed.). Foliage plant production. PrenticeHall, Englewood Cliffs, N.J.

Prasad, M. 1997. Physical, chemical and biological properties of coir dust. Acta Hort. 450:21-29.

Radin, J.W. and J.S. Boyer. 1982. Control of leaf expansion by nitrogen nutrition in sunflower plants: Role of hydraulic conductivity and turgor. Plant Physiol. 69:771-775.

Stamps, R.H. and M.R. Evans. 1997. Growth of Dieffenbachia maculata 'Camille' in growing media containing sphagnum peat or coconut coir dust. HortScience 32:844-847.

Stamps, R.H. and M.R. Evans. 1999. Growth of Dracaena marginata and Spathiphyllum 'Petite' in sphagnum peat- and coir dust-based growing media. J. Environ. Hort. 17:49-52.

Warncke, D.D. and D.M. Krauskopf. 1983. Greenhouse growth media: Testing and nutrition guidelines. Michigan State Univ. Coop. Ext. Serv. Bul. E-1736.

Yelanich, M.V. and J.A. Biernbaum. 1993. Rootmedium nutrient concentration and growth of poinsettia at three fertilizer concentrations and four leaching fractions. J. Amer. Soc. Hort. Sci. 118:771-77. 